\title{
OPTIMALISASI LINGKUNGAN PENDIDIKAN DI TENGAH PANDEMI COVID-19
}

\author{
${ }^{1)}$ Isnawati Nur Afifah Latif, Program Studi Pendidikan Agama Islam, Fakultas Tarbiyah, \\ Institut Agama Islam Nahdlatul Ulama (IAINU) Tuban, \\ email : isnawatinurafifahlatif@stitmatuban.ac.id
}

\begin{abstract}
The result of students development depends on education received from any it experienced environtmental education. The third environment called "triplecenter of education" can be explained as family, school, and people society. To get the best result from family education, teachers must concern on a couple of rules: 1) Attempt well-circumstance on the family environment; (2) Each family members should learn to hold on each their due and responsibility; (3) Parents and another adults on a family should know each character of the kids on their family; (4) We should keep away from anything destruct the development of children soul; and (5) Let our kids associate with their friends on the same age in the family environment. When kids growing up, they will be an member of people society who has each diversity. School environment is the next destination after kids passing through from family environment to complete the children education process. Teacher on the school not only have an responsibility to educate, but also to improve the cognitive, psychomotor, and affective aspect of the students. After passing through school environment, the education process next to social education in the people society environment. People society means a bunch of many families which have each different rules on it. When we was young, we only have due only, but since we growing as adults, we have wider responsibility on our hands begin from responsibility on our family, on our daily task in the school, people society, until our task on country and God. The emergence of Covid-19 pandemic has an effect on education system and force us to do "learning from home", it should adapt to government rules to prevent the speread of pandemic. Learning from home system needs "triplecenter of education" to keep education goals can be fully achieved.
\end{abstract}

Keywords: Optimalitation, Educational environment, Pandemic era of covid-19

\section{Pendahuluan}

Akhir tahun 2019 hingga bulan April tahun 2020 masih menjadi perbincangan di tengah masyarakat dan menjadi perhatian dunia akibat banyaknya angka kematian yang disebabkan oleh virus corona. Bahkan pada 11 Maret 2020, organisasi kesehatan dunia WHO menetapkan virus corona covid-19 sebagai pandemi. ${ }^{1}$ Kewaspadaan akan akibat dari pandemi ini mengharuskan semua negara untuk segera bertindak membuat kebijakan yang mengatur kegiatan warganya agar pandemi ini berkurang. Mulai dari membatasi kegiatan di luar rumah, bahkan jika dirasa perlu dapat membuat kebijakan agar warga masyarakatnya menghentikan aktivitas di luar ruangan.

1 Raden Trimutia Hatta. Alasan WHO Tetapkan Virus Corona COVID-19 sebagai Pandemi. https://www.liputan6.com/global/read/4200134/alasan-who-tetapkan-virus-corona-covid-19-sebagai-pandemi (diakses 12 Maret 2020) 
Pemerintah Indonesia juga merespon adanya pandemi ini. Presiden Jokowi dalam konferansi pers di Istana Bogor pada minggu 15 Maret 2020 menghimbau masyarakat untuk bekerja dari rumah, belajar dari rumah, dan ibadah dari rumah untuk meningkatkan kewaspadaan terhadap penyebaran virus corona covid-19 di Indonesia (Purnamasari, 2020). ${ }^{2}$ Dengan semua aktivitas masyarakat dipusatkan di satu tempat, yaitu rumah, diharapkan masyarakat tetap produktif walapun berada di dalam rumah

Himbauan presiden tersebut disusul keluarnya surat edaran dari berbagai tingkat pemerintahan di bawahnya, mulai dari tingkat kementerian sampai pada pemerintahan daerah yang menjadi dasar berbagai lembaga untuk membuat aturan terkait bekerja dari rumah, belajar dari rumah, dan beribadah dari rumah. Tidak terkecuali bidang pendidikan, juga harus menyesuaikan diri dengan adanya himbauan tersebut.

Berdasarkan latar belakang sebelumnya, maka rumusan masalah yang dapat dipaparkan adalah: 1)apa saja lingkungan pendidikan yang ada disekitar kita?; serta 2)bagaimana mengoptimalkan lingkungan pendidikan di tengah pandemi covid-19? Berangkat dari permasalahan tersebut, maka penelitian ini bertujuan untuk mendeskripsikan jenis lingkungan pendidikan yang ada disekitar dan mendeskripsikan optimalisasi lingkungan pendidikan di tengah pandemi covid-19.

Manusia sebagai makhluk sosial pasti akan selalu bersentuhan dengan perilaku sosial dimana manusia pasti membutuhkan manusia yang lain agar tetap dapat melanjutkan kehidupannya. Peserta didik harus mengalami perkembangan mulai semenjak dilahirkan sampai menjadi manusia dewasa, menjadi orang yang dapat berdiri sendiri dan bertanggung jawab sendiri dalam masyarakat. Baik buruknya hasil perkembangan tersebut bergantung pada pendidikan yang diterima dari berbagai lingkungan pendidikan.

Proses pendidikan berlangsung di tengah-tengah lingkungan pendidikan. Baik itu lingkungan keluarga, sekolah, dan masyarakat. Dengan adanya himbauan belajar dari rumah kegiatan pendidikan dapat dikatakan berpusat di rumah. Keluarga berperan penting untuk mensukseskan kegiatan belajar dari rumah. Kesuksesan peran dari keluarga akan menjadi maksimal jika di dukung oleh masyarakat dan sekolah.

2 Deti Mega Purnamasari. Jokowi: Saatnya Kerja dari rumah, Belajar dari Rumah, Ibadah di Rumah. https://nasional.kompas.com/read/2020/03/15/14232961/jokowi-saatnya-kerja-dari-rumah-belajar-dari-rumahibadah-di-rumah (diakses 15 MAret 2020) 
Dukungan dari lingkungan masyarakat dan sekolah untuk kegiatan pendidikan di lingkungan keluarga dapat berupa menyamakan tujuan akhir dari proses pendidikan. Melalui pendidikan, peserta didik diharapkan menjadi manusia yang dapat mengembangkan kemampuannya untuk memenuhi kebutuhan hidupnya sesuai dengan norma hukum yang berlaku. Pelaksanaan pendidikan mengupayakan hak dari peserta didik dapat terpenuhi di tengah kewaspadaan akan semakin meluasnya pandemi covid-19.

Tiga lingkungan tersebut di atas harus dimaksimalkan perannya agar tujuan pendidikan dapat tercapai. Walaupun dengan segala keterbatasan gerak langkah, dengan memaksimalkan fasilitas yang ada, upaya mewujudkan manusia terdidik diharapkan tetap dapat terlaksana. Untuk itu, perlu adanya kajian tentanng optimalisasi lingkungan pendidikan di tengah pandemi covid19.

\section{Metodologi}

Rancangan riset yang digunakan merupakan studi pustaka (library research), sumber data diperoleh dari dokumen artikel, jurnal penelitian, dan sumber pustaka lain terkait variabel yang akan diteliti yaitu lingkungan pendidikan dan pandemic covid-19. Data yang telah terkumpul kemudian akan melalui reduksi data supaya pembahasan menjadi lebih fokus dan bisa menjawab permasalahan yang telah dirumuskan.

\section{Hasil}

\section{A. Memahami Lingkungan Pendidikan}

\section{Pengertian Lingkungan Pendidikan}

Dalam arti luas, lingkungan mencakup iklim, geografis, tempat tinggal, adat istiadat, pengetahuan, pendidikan, dan alam. Dengan kata lain, lingkungan ialah segala sesuatu yang tampak dan terdapat dalam alam kehidupan yang senantiasa berkembang. Lingkungan mencakup seluruh yang ada, baik mausia maupun benda buatan manusia, atau alam yang bergerak dan tidak bergerak,kejadian-kejadian atau hal-hal yang mempunyai hubungan dengan seseorang. Sejauh mana seseorang berhubungan dengan lingkungannya, sejauh itu pula terbuka peluang masuknya pengaruh pendidikan kepadanya. Tetapi keadaan-keadaan itu tidak selamanya bernilai pendidikan. Bisa saja sebaliknya, mengurangi pengalaman berkembangnya.$^{3}$

\section{Jenis Lingkungan Pendidikan}

\footnotetext{
${ }^{3}$ Tatang S. Ilmu Pendidikan. 2012. Jakarta: Pustaka Setia. Hlm. 40
} 
Baik buruk hasil perkembangan peserta didik, bergantung pada pendidikan yang diterima peserta didik dari berbagai lingkungan pendidikan yang dialaminya. Lingkungan-lingkungan pendidikan jika dikelompokkan menjadi tiga kelompok besar adalah sebagai berikut:

a. Lingkungan Keluarga

Pendidikan di lingkungan keluarga menjadi dasar dari rangkaian proses pendidikan yang ditempuh peserta didik. Pendidikan keluarga mengawali proses terjadinya pendidikan. Berhasil tidaknya pendidikan di sekolah dan masyarakat bergantung dan dipengaruhi pendidikan dalam keluarga. Hasil-hasil pendidikan yang diperoleh peserta didik dalam keluarga menentukan pendidikan selanjutnya.

Pendidikan dari orang tua terhadap anak merupakan pendidikan yang didasari dengan kasih sayang. Orang tua adalah pendidik sejati karena kodratnya. Hal ini berarti pendidikan didasarkan dari kebutuhan peserta didik, yaitu anak, yang mana pendidikan ditempuh dengan mengesampingkan keinginan dan kesenangan sendiri. Pendidikan kasih sayang harus dijaga tujuan dan prosesnya, agar tidak berubah menjadi pendidikan yang memanjakan. Kasih sayang harus dilengkapi dengan pandangan yang benar tentang sikap orang tua terhadap anak.

Rasa khawatir orang tua yang berlebih terhadap anak juga dapat berpengaruh kurang baik. Karena kekhawatirannya, orang tua mempergunakan larangan sebagai satu-satunya alat pendidikan. Sehingga anak mempunyai rasa harga diri kurang, tidak berani berbuat dan bertindak atas inisiatif sendiri, selalu meminta pertolongan kepada orang lain, sukar bergaul dengan teman-temannya, dan lain-lain.

Untuk mendapatkan hasil yang baik dari pendidikan di lingkungan keluarga, beberapa aturan berdasarkan ilmu pendidikan yang perlu diperhatikan oleh pendidik ialah:

1) Upayakan suasana yang baik dalam lingkungn keluarga

Keluarga terutama orang tua hendaknya selalu berusaha agar di lingkungan keluarga selalu terdapat tolong-menolong, kasih sayang antar anggota-anggota keluarga, dan harus diikuti suasana kegembiraan dan ketentraman. Dalam keluarga yang baik selalu akan terdapat kejujuran, kesetiaan, keteguhan hati, kesabaran, kerajinan, kerapian, dan kebersihan antar anggota keluarganya.

2) Tiap anggota keluarga hendaklah belajar berpegang pada hak dan kewajiban masingmasing 
Orang tua secara bertahap harus memperkenalkan kewajiban seorang anak sebagai anggota keluarga. Untuk itu, anak harus dibiasakan mengerjakan tugas-tugas seperti mencuci baju sendiri, mandi, makan, tidur pada waktunya, ikut membantu mengasuh adik, berperan dalam menjaga kebersihan rumah, dan lain-lain. Jika tipa anggota keluarga mengetahui kewajibannya menurut aturan yang berlaku dalam keluarga, maka akan tercipt ketertiban dan ketentraman di dalamnya.

3) Orang tua serta orang dewasa lainnya dalam keluarga hendaklah mengetahui perilaku dan watak anak

Banyaknya waktu yang dihabiskan bersama anak menimbulkan ikatan batin yang kuat. Saat orang tua menemani anak bermain atau bersama-sama di kegiatan lainnya membuat orang tua memahami perilaku dan watak anak. Jika masing-masing anggota keluarga saling mengetahui perilaku dan watak maka akan dapat menghindarkan perselisihan yang berlebihan, bahkan akan mendatangkan kerukunan keluarga.

4) Hindarkan segala sesuatu yang dapat merusak perkembangan jiwa anak Orang tua tidak boleh melontarkan kalimat negatif kepada anak yang mengakibatkan anak menjadi berkecil hati. Pujian atau kalimat dukungan lebih bijaksana diucapkan. Demikian juga tidak baik jika orang tua menjadikan hukuman sebagai alat pendidikan satu-satunya. Anak yang sering mendapatkan hukuman akan cenderung untuk melawan hukuman. Hukuman, larangan dan teguran dapat digunakan seperlunya saja, atau sebagai alat terakhir dalam mendidik.

5) Biarkanlah anak bergaul dengan teman-temannya di lingkungan keluarga

Kekhawatiran orang tua terhadap pengaruh buruk pada anak dari temantemannya merupakan hal yang manusiawi. Tetapi perlu diingat, bahwa anak suatu saat nanti akan menjadi bagian dari masyarakat yang memiliki beragam karakter. Pergaulan anak dengan teman-temannya penting bagi perkembangan jiwa, terutama perkembangan perasaan sosial dan karakternya.

\section{b. Lingkungan Sekolah}

Sekolah sebagai lingkungan yang melanjutkan lingkungan keluarga dalam melengkapi proses pendidikan anak. Anak sebagai peserta didik dan Guru sebagai pendidik. Guru di sekolah memiliki tanggung jawab untuk mendidik, tidak hanya untuk mengajar. Guru diharapkan dapat ikut membantu menambah kemampuan peserta didik baik dari segi 
kognitif, psikomotorik maupun afektif. Dengan kata lain, tanggung jawab Guru tidak hanya mengajar untu menambah pegetahuan peserta didik, tetapi juga bertanggung jawab mendidik, membuat peserta didik memiliki karakter yang baik.

Di sekolah terdapat aturan-aturan yang harus ditaati peserta didik. Peserta didik harus beradaptasi dengan aturan yang berlaku di sekolah. Peraturan dan tuntutan dari sekolah kepada peserta didik dipengaruhi kebutuhan yang ada di masyarakat. Semakin tinggi tingkat kebutuhan masyarakat, maka kebudayaan di sekolah pun semakin tinggi. Sekolah dan keluarga dapat bekerja sama untuk menyempurnakan pendidikan peserta didik. Orang tua mendapat pengetahuan dan pengalaman mendidik dari guru, sebaliknya, guru dapat memperoleh keterangan-keterangan dari orang tua tentang kehidupan dan sifat-sifat anak. Keterangan dari orang tua, guru dapat mengetahui keadaan lingkungan sekitar peserta didik.

\section{c. Lingkungan Masyarakat}

Seorang anak setelah dilahirkan berada di tengah masyarakat kecil yang kita kenal dengan sebutan keluarga. Di dalam keluarga terdapat aturan-aturan tidak tertulis yang harus ditaati oleh anggota keluarga, termasuk anak. Anak harus mulai dibiasakan menaati aturan. Walaupun pada awalnya anak bersikap pasif, seiring berjalan waktu dan beranjak dewasa seorang anak akan bersikap pasif dan aktif terhadap aturan keluarga.

Saat anak dewasa, dia akan menjadi anggota masyarakat yang memiliki banyak keragaman. Masyarakat merupakan kumpulan atau golongan dari keluarga-keluarga yang masingmasing memiliki aturan di dalamnya. Masing-masing anggota golongan memiliki hak dan kewajiban. Saat masih kecil, anak memiliki hak saja, semakin dewasa semakin luas kewajiban yang harus dilakukannya. Dari kewajiban di dalam keluarga, meluas menjadi kewajiban terhadap tugas-tugas, baik tugas di sekolah, masyarakat, hingga negara dan Tuhan. Menjadi anggota masyarakat menjadikan anak mengenal pendidikan sosial.

Segala pengaruh yang datang dari orang lain disebut pengaruh lingkungan sosial. Pendidikan sosial merupakan pengaruh yang sengaja didatangkan dari pendidikanpendidikan itu sendiri. Pengaruh ini berguna untuk menjadikan anak sebagai anggota yang baik dan dapat mengendalikan diri di tengah kelompoknya dan di mana saja dia berada. Dengan demikian, masyarakat meiliki keikutsertaan membimbing pertumbuhan dan perkembangan seorang anak 


\section{B. Tujuan Pendidikan}

Tujuan pendidikan merupakan deskripsi tentang capaian yang diharapkan pendidik dari peserta didiknya setelah mereka melalui proses pendidikan. Jika pendidik merumuskan atau menentukan tujuan, maka ia dapat memilih atau merancang tahapan pendidikan dan memilih penunjang proses pendidikan, seperti metode yang akan digunakan, dan memilih bahan-bahan pengajaran sebagai bagian dari proses pendidikan. Pengukuran dan evaulasi dari proses pendidikan akan sulit diketahui karena tidak dirumuskannya tujuan pendidikan. Tanpa adanya rumusan tujuan yang jelas, akan sulit untuk mengorganisasikan kegiatan-kegiatan dan usaha-usaha peserta didik dalam mencapai tujuan dari pendidikan itu sendiri. Bagi pendidik rumusan tujuan pendidikan juga memudahkannya untuk melakukan balikan (feedback) ke peserta didik dalam proses pendidikan. Dari hasil evaluasi dan balikan dari proses pendidikan juga dapat digunakan untuk menimbang kembali rumusan tujuan pendidikan, tujuan manakah perlu diperbaharui atau diubah. Pendidikan merupakan suatu upaya dan kegiatan yang berproses melui tahapan-tahapan dan tingkatan-tingkatan. Tujuan dari pendidikan memiliki tahapan dan tingkatan. Tujuan pendidikan bukanlah suatu benda yang tetap dan statis, tetapi merupakan suatu keseluruhan dari kepribadian seseorang, dan berkenaan dengan seluruh aspek kehidupannya. ${ }^{4}$ Tujuan-tujuan pendidikan lebih detailnya dibagi ke dalam beberapa jenis, sebagai berikut:

\section{Tujuan Umum}

Tujuan umum merupakan tujuan yang akan dicapai dari semua kegiatan pendidikan, baik dengan pengajaran atau dengan cara lain. Tujuan itu meliputi seluruh aspek kemanusiaan yang meliputi sikap, tingkah laku, penampilan, kebiasaan dan pandangan. Tujuan umum ini berbeda pada setiap tingkat usia, kecerdasan, situasi, kondisi, dengan kerangka yang sama. Cara atau alat yang paling efektif dan efisien untuk mencapai tujuan pendidikan adalah dengan pengajaran. Karena itu, pengajaran sering diidentikkan dengan pendidikan, meskipun sebenarnya kedual ini berbeda.

Tujuan umum disebut juga tujuan akhir, tujuan sempurna, atau tujuan terakhir. Tujuan umum ialah tujuan di dalam pendidikan yang seharusnya menjadi tujuan semua pendidik baik orang tua dan pendidik lainnya, yang telah ditetapkan oleh pendidik dan selalu dihubungkan dengan kenyataan-kenyataan yang terdapat pada peserta didik itu sendiri dan dihubungkan dengan syarat-syarat dan cara-cara atau alat-alat pendidikan untuk mencapai tujuan umum

\footnotetext{
${ }^{4}$ Akhmad Muhaimin Azzet. Urgensi Pendidikan Karakter di Indonesia. 2009. Yogjakarta: Arruz Media. Hlm. 54-58
} 
itu. Tujuan umum tidak dapat dicapai kecuali setelah melalui proses pengajaran, pengalaman, pembiasaan, penghayatan, dan keyakinan akan kebenarannya. Tahapan ini dalam pendidikan formal dirumuskan dalam bentuk tujuan kurikuler yang selanjutnya dikembangkan dalam bentuk tujuan instruksional.

Tujuan umum selalu dilaksanakan dalam bentuk-bentuk yang khusus, mengingat faktorfaktor yang ada pada peserta didik sendiri dan lingkungannya, seperti:

a. Sifat pembawaan peserta didik seperti usia, jenia kelamin, watak dan kecerdasannya,

b. Kemungkinan-kemungkinan dan kesanggupan-kesanggupan keluarga peserta didik, miskin atau kaya, terpelajar atau tidak, dan lain-lain. Masih modernkah masyarakat di sekitar peserta didik itu? Pakah adat-istiadat masyarakat menghambat atau memperlancar pendidikan peserta didik? Dan sebagainya,

c. Tempat dan masyarakat yang menjadi tujuan peserta didik itu. Jabatan-jabatan, pekerjaan-pekerjaan, dan fungsi-fungsi mayarakat apakah yang diperlukan? pertanian, perindustrian, perekonomian, pemerintahan, perdagangan, dan sebagainya adalah lapangan-lapangan kemasyarakatan yang memerlukan syaratsyarat tertentu dari tiap-tiap orang. Dengan kata lain, tidak semua anggota masyarakat meminta syarat-syarat yang sama,

d. Tugas badan-badan dan tempat pendidikan. Keluarga, sekolah, badan-badan keagamaan, badan-badan sosial, dan sebagainya sudah tentu menjadi mempunyai tugas yang berbeda-beda dalam mendidik anak. Masing-masing akan melihat peserta didik dari sudut pandangnya sendiri-sendii,

e. Tugas negara dan masyarakat di sini dan sekarang. Keadaan manusia di masa dahulu berbeda dengan sekarang. Maka dari itu, tujuan umum dengan sendirinya akan mengalami penentuan yang berbeda juga,

f. Kemampuan-kemampuan yang ada pada pendidik itu sendiri. Kemampuankemampuan, pengetahuan, dan kehidupan pendidik, turut menentukan tujuan pendidikan.

g. Tujuan umum ini dengan demikian harus ditentukan yang sungguh-sungguh konkret dengan memperhitungkan dan memperhatikan segala kenyataan. 
2. Tujuan tak sempurna

Tujuan tak sempurna atau tak lengkap ialah tujuan mengenai segi-segi kepribadian manusia yang ingin dicapai dengan pendidikan. Seperti segi-segi yang berhubungan dengan nilai-nilai hidup tertentu, seperti keindahan, kesusilaan, keagamaan, kemasyarakatan, pendidikan intelektual, da lain-lain yang masing-masing dilaksanakan untuk mencapai tujuan yang terkandung di dalam masing-masing aspek itu sendiri. Tujuan tak sempurna ini bergantung dan tidak terlepas dari tujuan umum. Misalnya, peserta didik mengajarkan berbicara dengan sopan dan santun.

3. Tujuan sementara

Tujuan sementara merupakan tempat-tempat perhentian sementara pada saat akan menuju ke tujuan umum. Seperti peserta didik dilatih untuk belajar mengenai kebersihan, belajar berbicara, belajar berbelanja, belajar bermain-main bersama teman-temannya, dan lain-lain. Pendidik melatih peserta didik berbicara, sampai peserta didik bisa berbicara. Dalam hal ini tujuan sementara tercapai, tetapi tidak hanya berhenti di situ. Pendidik melanjutkan proses pendidikan dengan menajarkan peserta didik berbicara yang sopan dan santun, agar dapat berbuat susila (tujuan tak lengkap), dan seterusnya. Tujuan sementara ini merupakan tingkatan-tingkatan untuk menuju kepada tujuan umum. Untuk mencapai tujuan sementara, dalam penerapannya harus mengingat dan memperhatikan jalannya perkembangan kemampuan peserta didik. Untuk hal ini diperlukan kajian dari lingkup psikologi perkembangan.

\section{Tujuan perantara}

Tujuan perantara bergantung pada tujuan sementara. Contoh dari tujuan perantara misalnya jika tujuan sementaranya agar peserta didik dapat berbicara, maka tujuan perantaranya adalah metode-metode yang dipilih dan digunakan pendidik agar peserta didik dapat berbicara.

5. Tujuan insidental

Tujuan insidental muncul sebagai kejadian-kejadian yang terlepas dari tahapan menuju tujuan umum. Misalkan seorang ayah memanggil anaknya yang sedang bermain di luar rumah. Tujuannya memanggil agar anak tidur siang, untuk makan siang, atau agar bersama ayahnya. Di sini ayah menuntut untuk dituruti kemauannya. Berbeda dengan jika tujuan ayah memanggil anaknya agar makan siang dengan keluarga sehingga terjalin rasa kebersamaan yang kuat antar anggota keluarga, maka hal ini desebut sebagai tujuan perantara. 


\section{Tanggung Jawab Pendidikan dalam Islam}

Tanggung jawab pendidikan diselenggarakan dengan kewajiban mendidik. Secara umum mendidik ialah membantu peserta didik di dalam perkembangan dari daya-dayanya dan di dalam penetapan nilai-nilai. Bantuan atau bimingan itu dilakukan dalam pergaulan antara pendidik dan peserta didik dalam situasi pendidika yang terdapat dalam lingkungan keluarga, sekolah, maupun masyarakat.

Bimbingan dapat bersifat bimbingan pasif dan aktif. Bimbingan pasif artinya pendidik tidak mendahului perkembangan masa ingin tahu peserta didik akan hal-hal baru, tidak selalu memberikan bantuan kepada peserta didik saat menemui permasalahan di tengah pengalaman belajarnya. Pendidik menunggu dengan seksama dan sabar. Sedangkan bimbingan aktif terletak di dalam: (a) peran bimbingan pendidik pada saat perkembangan daya dari peserta didik memperbaharui pengetahuannya tanpa mendominasi pengalaman belajar peserta didik; (b) pemberian pengetahuan dan keterampilan yang penting untuk masa depan peserta didik; dan (c) peran pendidik saat membangkitkan motivasi-motivasi yang dapat menggerakkan peserta didik untuk bertindak sesuai dengan tujuan hidupnya. Pemberian bimbingan ini dilakukan oleh orang tua di dalam lingkungan keluarga, para pendidik di lingkungan sekolah dan juga para masyarakat di lingkungan sosial lainnya.

Orang tua merupakan pendidik utama dan pertama bagi peserta didik. Dari orang tualah peserta didik menerima pendidikan pertama saat peserta didik baru lahir di tengah-tengah keluarganya. Dengan demikian bentuk pertama dari pendidikan di dapat pada lingkungan keluarga. Pada umumnya, pendidikan di dalam lingkungan keluar bukan berasal dari kesadaran dan pengertian yang muncul dari pengetahuan mendidik. Melainkan karena secara kodrati suasana dan strukturnya memberikan kemungkinan alamiah untuk membangun situasi pendidikan di dalam kehidupan berkeluarga. Situasi pendidikan ini terwujud berkat adanya pergaulan dan hubungan saling mempengaruhi secara timbal balik antara orang tua dan anak.

Orangtua, atau ibu dan ayah, memgang peran yang penting dan sangat berpengaruh atas pendidikan anak-anaknya. Dimulai sejak seorang anak lahir, ibunya lah yang selalu di sampingnya. Oleh karena itu, anak meniru perangai ibu dan memiliki kedekata yang lebih apabila seorang ibu menjalankan tugasnya dengan baik. Ibu yang mula-mula menjadi temanyya, yang mula-mula dipercayainya. Dengan memahami segala yang terkandung dalam hati anaknya 
disertai kasih sayang, jika anak telah mulai menuju dewasa, dapatlah ibu mengambil hati anaknya untuk selama-lamanya.

Pengaruh ayah terhadap anaknya juga besar. Cara ayah melakukan pekerjaanya sehari-hari berpengaruh pada cara pekerjaan anaknya. Ayah merupakan penolong utama, lebih-lebih pada anak yang menuju usia remaja, baik laki-laki maupun perempuan, bila ayah dekat dengan anaknya akan dapat memahami hati anaknya.

Pada dasarnya kenyataan-kenyataan di atas berlaku dalam kehidupan keluarga apapun latar belakangnya. Hal ini menunjukkan ciri-ciri dan watak tanggung jawab setiap orang tua atas kehidupan anak mereka saat ini dan di masa depan. Bahkan para orang tua umumnya merasa bertanggung jawab atas segala kelangsungan hidup anaknya. Dari sini tidak diragukan lagi bahwa pendidikan peserta didik secara mendasar berada pada tanggung jawab orang tua. Baik taggung jawab ini diakui secara sadar atau tidak, hal ini erupakan fitrah yang telah digariskan Allah SWT kepada setiap orang tua. ${ }^{5}$

Di samping itu pangkal ketentraman dan kedamaian hidup terletak dalam keluarga. Islam memandang bukan hanya sebagai persekutuan hidup terkecil saja, melainkan lebih dari itu. Keluarga sebagai lembaga hidup manusia yang memberi pilihan peluang kepada para anggota keluarganya untuk hidup celaka atau bahagia dunia dan akhirat.

Pertama-tama yangdiperintahkan Allah kepada Nabi Muhammad dalam mengembangkan agama Islam adalah untuk mengajarkan agama itu dalam keluarganya, baru kemudian kepada masyarakat luas. Hal ini berarti di dalamnya terkandung makna bahwa keselamatan keluarga harus lebih dulu mendapat perhatian atau harus didahulukan daripada keselamatan masyarakat. Karena keselamatan masyarakat pada hakikatnya tertumpu pada keselamatan keluarga. Allah SWT berfirman dalam surat Asy Syu'ara ayat 214 yang artinya "dan berilah peringatan kepada kerabat-kerabatu yang terdekat".

Demikian pula dalam Islam meemerintahkan kepada orang tua untu bertindak sebagai kepada dan pemimpin dalam keluarganya. Serta erkewajiban untuk memelihara keluarganya dari api neraka sebagaimana tercantum dalam quran surat At Tahrim ayat 6. Menganai kewajiban dan tanggung jawab orang tua untuk mendidik dan membimbing perkembangan anak-anaknya, maka tanggung jawab pendidikan ini ada dasarnya tidak bisa dibebankan kepada orang lain. Sebab, guru, pemimpin dalam perintahan dan masyarakat, dalam memikul tanggung jawab pendidikan

\footnotetext{
${ }^{5}$ Ahmad Tafsir. Ilmu pendidikan dalam perspekif Islam. 2014. Bandung: Remaja Rosdakarya. Hlm. 64
} 
hanyalah bersifat keikutsertaan saja. Dengan kata lain, tanggung jawab pendidikan yang dipikul oleh para pendidik selain orang tua adalah merupakan pelimpahan tanggung jawab orang tua yang karena satu dan lain hal tidak mungkin melaksanakan pendidikan kepada peserta didik secara sempurna.

Tanggung jawab pendidikan Islam yang menjadi beban orang tua seurang-kurangnya harus dilaksanakan dalam tujuan:

1. Memelihara dan membesarkan anak. Ini adalah bentuk yang paling sederhana dari tanggung jawab orang tua dan merupakan dorongan alamiah untuk mempertahankan kelangsungan hidup manusia,

2. Melindungi dan menjamin kesamaan, baik jasmani maupun rohani, dari berbagai penyakit dan dari penyelewengan kehidupan dan tujuan hidup yang sesuai dengan falsafah hidup dan agama yang dianutnya,

3. Memberi pengajaran dalam arti yang luas sehingga anak memperoleh peluang untuk memiliki pengetahuan dan kecakapan seluas dan setinggi mungkin yang dapat dicapainya,

4. Membahagiakan anak, baik dunia maupun akhirat, sesuai dengan pandangan dan tujuan hidup seorang muslim.

Melihat tanggung jawab pendidikan Islam yang meliputi kehidupan dunia da akhirat dalam arti yang luas, dapatlah diperkirakan bahwa para orang tua tidak mungkin dapat memikulnya sendiri secara sempurna. lebih-lebih dalam masyarakat yang senantiasa berkembang maju. Hal ini bukan merupakan suatu keburukan atau aib. Karena tanggung jawab tersebut tidaklah harus sepenuhnya dipikul orang tua secara sendiri-sendiri. Oarang tua sebagai manusia memiliki keterbatasanketerbatasan. Namun demikian, setiap orang tua tidak dapat mengelak dari tanggung jawab mendidik anaknya. Artinya, pada akhirnya, tanggung jawab pendidikan berada dan kembali kepada orang tua lagi.

Kenyataan hidup telah membuka peluang kepada pendidik selain orang tua, untuk ikut serta memikul tanggung jawab pendidikan. Peluang itu pada dasarnya terletak pada kemungkinan apakah pendidik, selain orang tua, dapat memenuhi tugas dan kewajibannya sesuai harapan para orang tua. Dengan demikian, peluang ini hanya mungkin dapat dipenuhi oleh setiap orang dewasa yang mempunyai harapan, cit-cita, pandangan hidup, dan kehidupan keagamaan yang sesuai dengan apa yang dihajatkan oleh para orang tua untuk anak-anaknya. 
Guru dalah pendidik profesional. Secara implisit, guru telah merelakan dirinya menerima dan memikul sebagian tanggung jawab yang dipikul orang tua. Orang tua saat menyerahkan anaknya ke sekolah, sekaligus mempercayakan sebagian tanggung jawab pendidikan anaknya kepada guru. Hal itu menunjukkan pula bahwa orang tua tidak mungkin menyerahkan anaknya kepada sembarang guru.

Dilihat dari ilmu pendidikan Islam, maka secara umum untuk menjadi seorang guru yang baik dan diperkirakan dapat memenuhi tanggung jawab yang dibebankan kepadanya, hendaknya ia bertakwa kepada Allah, berilmu, sehat jasmanahnya, baik akhlaknya, bertanggung jawab dan berjiwa nasional. Guru sesuai dengan tujuan ilmu pendidikan Islam, tidak mungkin mendidik anak agar bertakwa kepada Allah jika ia sendiri tidak bertakwa. Sebab ia adalah teladan bagi peserta didiknya, sebagaimana Rasulullah menjadi teladan bagi umatnya. Sejauh apa seorang guru mampu memberikan teladan baik kepada peserta didiknya, sejauh itu pula diperkirakan ia akan berhasil mendidik mereka menjadi generasi penerus bangsa yang baik dan mulia.

Kesehatan jasmani kerapkali dijadikan salah satu syarat bagi mereka yang ingin menjadi guru. Kesehatan badan sangat mempengaruhi semangat bekerja. Kemudian budi pekerti yang baik juga penting dalam mendidik watak peserta didik. Guru yang tidak berakhlak baik tidak mungkin dipercayakan menjadi seorang gueuAnak-anak cenderung bersifat suka meniru. Yang dimaksud berakhlak baik dalam ilmu pendidikan Islam adalah akhlak yang sesuai dengan ajaran Islam. Seperti dicontohkan Rasulullah di antara kahlak seorang guru adalah:

1. Mencintai jabatannya sebagai seorang guru

Tidak semua orang menjadi guru karena panggilan jiwa. Di antara mereka ada yang menjadi guru karena berbagai latar belakang. Misalnya karena keadaan ekonomi, dorongan teman atau orang tua, dan sebagainya. Dalam keadaan bagaimanapun seorang guru harus mencintai pekerjaannya. Dan pada umumnya, kecintaan terhadap pekerjaannya akan bertambah besar apabila dihayati benar-benar keindahan dan kemuliaan tugas itu. Yang paling baik adalah apabila seseorang menjadi guru karena didorong oleh panggilan jiwanya.

2. Bersikap adil terhadap semua peserta didiknya

Anak-anak tajam pandangannya terhadap perlakuan yang tidak adil. Guru-guru, terlebih yang masih muda, kerapkali bersikap pilih kasih, guru laki-laki lebih memperhatikan peserta didik perempuan yang cantik atau yang pandai daripada yang lain. Hal ini jelas tidak baik. Guru harus memperhatikan semua anak dengan cara yang sama. 


\section{Berlaku sabar dan tenang}

Di sekolah kerapkali merasakan kekecewaankarena peserta didik kurang mengerti apa yang diajarkannya. Peserta didik yang tidak mengerti kadang-kadang menjadi pendiam atau sebaliknya membuat keributan-keributan. Hal itu sedah pasti mengecewakan guru, atau malah menyebabkannya putus asa. Dalam keadaan demikian, guru harus tetap tabah, sabar, sambil berusaha mengkaji maslahnya dengan tenang. Sebab, bisa jadi kesalahan terletak pada dirinya yang kurang simpatik atau cara mengajarnya yang kurang terampil atau bahan pelajaran yang belum terkuasai olehnya.

4. Guru harus berwibawa

Peserta didik membuat keributan dan berbuat kekehendaknya, lalu guru merasa jengkel, berteriak sambil memukul meja. Ketertiban dapat dikembalikan dengan kekerasan. Tetapi ketertiban karena kekerasan senantiasa bersifat semu. Guru yang semacam ini kurang berwibawa. Sealiknya, ada juga guru yang sesaat ketika ia memasuki dan menghadap dengan tenang kepada peserta didik yang sedang ribut, segera kelas menjadi tenang, padahal ia tidak melakukan kekerasan. Ia mampu menguasai peserta didik seluruhna. Inilah guru yang berwibawa.

5. Guru harus gembira

Guru yang gembira memiliki sifat humor, suka tertawa dan suka memberi kesempatan tertawa peserta didiknya. Dengan senyumnya ia memikat hati peserta didik. Sebab apabila proses belajar mengajar di kelas diselingi humor, gelak tawa, niscaya jam pelajaran terasa cepat berlalu. Guru yang gembira biasanya tidak lekas kecewa. Ia mengerti bahwa peserta didiknya tidak bodoh, tetapi belum tahu. Dengan gembira, ia mencoba menjelaskan kembali pelajaran sampai peserta didik memahaminya.

6. Guru harus bersifat manusiawi

Guru adalah manusia yang tidak lepas dari kekurangan dan cacat. Ia bukan manusi sempurna. Oleh karena itu ia harus berani melihat kekurangan-kekurangannya sendir dan segera memperbaikinya. Dengan demikian, pandangannya tidak picik terhadap kelakuan manusia umumnya dan peserta didik khususnya. Ia dapat melihat perbuatan yang salah menurut ukuran yang sebenarnya. Ia memberkan hukuman yang adil dan suka memaafkan apabila anak memperbaiki kesalahannya.

7. Bekerja sama dengan guru-guru lain 
Suasana di kalangan guru sebagian besar bergantung pada sikap dan kebijaksanaan guru kepala. Apabila guru-guru saling bententangan, peserta didik akan bingung dan tidak tahu apa yang diperblehkan dan mana yang dilarang.

8. Bekerja sama dengan masyarakat

Guru harus memiliki pandangan luas. Ia harus bergaul dengan semua golongan manusia dan secara aktif berperan serta dalam masyarakat. Sekolah hanya dapat berdiri di tengah-tengah masyarakat. Apabila guru rajin bergaul, suka mengunjungi orang tua peserta didik, ikut serta dalam perkumpulan-perkumpulan dan ikut serta dalam kejadian-kejadian penting di lingkungannya, maka masyarakat akan memberikan perhatiannya juga kepada sekolah.

Masyarakat turut serta memikul tanggung jawab pendidikan. Secara sederhana masyarakat dapat diartikan sebagai kumpulan individu dan kelompok yang diat oleh kesatuan negara, kebudayaan dan agama. Setiap masyarakat mempunyai cita-cita, peraturan-peraturan dan sistem kekuasaan tertentu.

Masyarakat, besar pengaruhnya dalam memberi arah terhadap pendidikan anak. Terutama para pemimpin masyarakat atau penguasa yang ada di dalamnya. Pemimpin masyarakat muslim tentu saja menghendaki agar setiap anak dididik menjadi anggota yang taat dan patuh menjalankan agamanya, baik dalam lingkungan keluarganya, anggota sepermainannya, kelompok kelasnya, dan sekolahnya. Jika anak telah dewasa diharapkan menjadi anggota yang baik pula sebagai warga dalam suatu desa, kota, dan negara.

Dengan demikian, di pundak mereka terpikul keikutsertaan membimbing pertumbuhan dan perkembangan anak. Ini berarti bahwa pemimpin dan penguasa dari masyarakat ikut bertanggung jawab terhadap penyelenggaraan pendidikan. Sebab, tanggung jawab pendidikan pada hakikatnya merupakan tanggung jawab moral dari setiap orang dewasa sebagai perseorangan maupun sebagai kelompok sosial. Tanggung jawab ini ditinjau dari segi ajaran Islam, secara implisit mengandung pula tanggung jawab pendidikan. ${ }^{6}$

Sekalipun Islam menekankan tanggung jawab perseorangan dan pribadi bagi manusia dan menganggapnya sebagai asas, ia tidaklah mengabaikan tanggung jawab sosial yang menjadikan masyarakat sebgai masyarakat solidaritas, berpadu dan bekerja sama membina dan mempertahankan kebaikan. Semua anggota masyarakat memikul tanggung jawab membina,

\footnotetext{
${ }^{6}$ Omar Muhammad al Toumy Syaibani. Falsafah Pendidikan Islam. Terjemahan Hasan Langgulung dan Broto. 1979. Jakarta: Bulan Bintang. Hlm. 381-390
} 
memakmurkan, memperbaiki, mengajak kepada kebaikan, memerintahkan yang makruf, melarang yang mungkar, dimana tanggung jawab manusia melebihi perbuatan-perbuatannya yang khas, perasaannya, pikiran-pikirannya, keputusan-keputusannya, dan maksud-maksudnya, sehingga mencakup masyarakat tempat ia hidup dan alam sekitar yang mengelilinginya. Islam tidak membebaskan manusia dari tanggung jawab tentang apa yang berlaku pada masyarakatnya dan apa yang terjadi di sekelilingnya atau terjadi dari orang lain. Terutama jika orang lain itu termasuk orang yang berada di bawah perintah dan pengawasannya, seperti istri, anak, dan lainlain. Dengan demikian jelaslah tanggung jawab dalam Islam bersifa perseorangan dan sosial sekaligus. Tanggung jawab ini tidak hanya bertanggung jawab terhadap perbuatannya dan perbaikan hidupnya, tetapi juga bertanggung jawab terhadap perbuatan orang-orang yang berada di bawah perintah, pengawasan, tangungannya dan perbaikan masyarakatnya. Hal ini berlaku atas diri pribadi, istri, bapak, guru, golongan, lembaga-lembaga pendidikan, dan pemerintah.

\section{Pandemi Covid-19}

Coronavirus merupakan keluarga besar virus yang menyebabkan penyakit pada manusia dan hewan. Pada manusia biasanya menyebabkan penyakit infeksi saluran pernapasan, mulai flu biasa hingga penyakit yang serius seperti Middle East Respiratory Syndrome (MERS) dan Sindrom Pernapasan Akut Berat/Severe Acute Respiratory Syndrome (SARS). Penyakit ini terutama menyebar di antara orang-orang melalui tetesan pernapasan dari batuk dan bersin. Virus ini dapat tetap bertahan hingga tiga hari dengan plastik dan stainless steel SARS CoV-2 dapat bertahan hingga tiga hari, atau dalam aerosol selama tiga jam. Virus ini juga telah ditemukan di feses, tetapi hingga Maret 2020 tidak diketahui apakah penularan melalui feses mungkin, dan risikonya diperkirakan rendah. ${ }^{7}$

Corona virus jenis baru yang ditemukan pada manusia sejak kejadian luar biasa muncul di Wuhan China, pada Desember 2019, kemudian diberi nama Severe Acute Respiratory Syndrome Coronavirus 2 (SARS- COV2), dan menyebabkan penyakit Coronavirus Disease-2019 (COVID19). COVID-19 termasuk dalam genus dengan flor elliptic dan sering berbentuk pleomorfik, dan berdiameter 60- $140 \mathrm{~nm}$. Virus ini secara genetic sangat berbeda dari virus SARS-CoV dan MERS-CoV. Penelitian saat ini menunjukkan bahwa homologi antara COVID-19 dan memiliki karakteristik DNA coronavirus pada kelelawar-SARS yaitu dengan kemiripan lebih dari 85\%.

\footnotetext{
${ }^{7}$ van Doremalen N, Bushmaker T, Morris DH, Holbrook MG, Gamble A, Williamson BN, et al. (March 2020). "Aerosol and Surface Stability of SARS-CoV-2 as Compared with SARS-CoV-1". The New England Journal of Medicine. Massachusetts Medical Society. doi:10.1056/nejmc2004973. PMID 32182409
} 
Ketika dikultur pada vitro, COVID-19 dapat ditemukan dalam sel epitel pernapasan manusia setelah 96 jam. Sementara itu untuk mengisolasi dan mengkultur vero E6 dan Huh-7 garis sel dibutuhkan waktu sekitar 6 hari.

Pada 31 Desember 2019, WHO China Country Office melaporkan kasus pneumonia yang tidak diketahui etiologinya di Kota Wuhan, Provinsi Hubei, China. Pada tanggal 7 Januari 2020, China mengidentifikasi pneumonia yang tidak diketahui etiologinya tersebut sebagai jenis baru coronavirus (novel coronavirus). Pada awal tahun 2020 NCP mulai menjadi pendemi global dan menjadi masalah kesehatan di beberapa negara di luar RRC. Berdasarkan World Health Organization (WHO) kasus kluster pneumonia dengan etiologi yang tidak jelas di Kota Wuhan telah menjadi permasalahan kesehatan di seluruh dunia. Penyebaran epidemi ini terus berkembang hingga akhirnya diketahui bahwa penyebab kluster pneumonia ini adalah Novel Coronavirus.

Pandemi ini terus berkembang hingga adanya laporan kematian dan kasus-kasus baru di luar China. Pada tanggal 30 Januari 2020, WHO menetapkan COVID-19 sebagai Public Health Emergency of International Concern (PHEIC)/Kedaruratan Kesehatan Masyarakat Yang Meresahkan Dunia (KKMMD). ${ }^{8}$ Pada tanggal 12 Februari 2020, WHO resmi menetapkan penyakit novel coronavirus pada manusia ini dengan sebutan Coronavirus Disease (COVID-19). COVID-19 disebabkan oleh SARS-COV2 yang termasuk dalam keluarga besar coronavirus yang sama dengan penyebab SARS pada tahun 2003, hanya berbeda jenis virusnya. Gejalanya mirip dengan SARS, namun angka kematian SARS (9,6\%) lebih tinggi dibanding COVID-19 (saat ini kurang dari 5\%), walaupun jumlah kasus COVID-19 jauh lebih banyak dibanding SARS. COVID-19 juga memiliki penyebaran yang lebih luas dan cepat ke beberapa negara dibanding SARS.

\section{E. Optimalisasi Lingkungan Pendidikan di Tengah Pandemi Wabah Covid-19}

Pembatasan interaksi fisik di masyarakat yang diputuskan pemerintah sebagai upaya menghentikan penyebaran COVID-10 mempengaruhi pelaksanaan berbagai bidang kehidupan. Tidak terkecuali bidang pendidikan. Keputusan pemerintah memindah proses pembelajaran dari sekolah menjadi di rumah membuat berbagai pelaksana pendidikan mengikuti alur yang dapat ditempuh sesuai kondisi lembaganya agar pembelajaran dapat tetap berlangsung. Pilihan yang

\footnotetext{
8 "Coronavirus Disease 2019 (COVID-19)". Centers for Disease Control and Prevention (CDC). Diakses 26 Februari 2020
} 
ditempuh yaitu dengan pemanfaaan teknologi sebagai media pembelajaran dalam jaringan (daring). Pelaksanaan daring memiliki beberapa hambatan, diantaranya penguasaan teknologi yang masih rendah, keterbatasan sarana dan prasarana, jaringan, ketidakstabilan jaringan internet, dan penambahan anggaran untuk mendukung proses belajar daring.

Kesadaran akan peran semua lingkungan pendidikan semakin nyata dirasakan saat pembelajaran daring dilaksanakan. Di lingkungan keluarga, disadari kembali bahwa tanggung jawab pendidikan anak mutlak ada pada orang tua. Pembelajaran daring mengharuskan orang tua terlibat dalam kegiatan belajar anaknya. Tentunya banyak pengalaman yang dirasakan orang tua ketika mendampingi anaknya belajar. Kesadaran akan pentingnya mengetahui hingga memahami teknologi yang mendukung pembelejaran anak, mengetahui apa saja yang dipelajari anak di sekolah, memaksimalkan budaya belajar saat dirumah yang membutuhkan waktu, biaya, dan energi harus segera diadaptasi orang tua agar anaknya sukses belajar dari rumah.

Dari proses ini diharapkan orang tua memiliki banyak peran, diantaranya mendampingi, membimbing, dan mengarahkan anak-anak dalam penyelesaian proses pembelajaran. Orang tua juga dapat memahami bahwa dukungan dan peran mereka sangat dibutuh anak-anak dalam proses pembelajaran setiap hari. Pentingnya keterampilan membagi waktu dan menyelesaikan masalah secara tepat menjadikan keberhasilan dalam menuntaskan tugas dari guru. Karakter anak yang mungkin belum diketahui orang tua kemudian akan Nampak pada saat pengerjaan tugas. Dari kondisi ini diharapkan akan dipahami Bersama pentingnya pendidikan diawali dari keluarga sebagai tempat pertama dalam pembentukan karakter anak.

Agar tidak disalahartikan sebagai hari libur, peserta didik diberikan tugas-tugas pembelajaran agar tetap dalam suasana belajar. Karena itu, guru diharuskan mendisain sedemikian rupa tugastugas bagi peserta didik. sehingga, guru perlu membangun komunikasi dengan orang tua peserta didik agar pembelajaran daring tetap terlaksana secara intens dengan hasil yang tidak terpaut jauh dengan pembelajaran langsung di kelas. Dari sini semakin diketahui pentingnya sinergi lingkungan keluarga dan sekolah.

Saat pembelajaran daring, guru diharuskan agar tetap kreatif menyajikan pembelajaran daring secara menyenangkan dan mudah dipahami sehingga peserta didik tetap semangat dan produktif di rumah. Guru juga diminta menunjukkan kemampuan memamnaatkan media teknologi dengan presentasi, penugasan, kuis, dan pemberian tugas proyek. Penyajian pembelajaran yang terencana dan efektif dalam keterbatasan waktu dapat diatasi dengan mempersiapkan rencana 
pembelajaran yang berkualitas dan mengatur langkah-langkah pembelajaran dengan detail. Tantangan lainnya yatu guru diharapkan mampu menyatukan persepsi dan konsentrasi peserta didik yang berjauhan. Hal ini dapat dilakukan guru jika memiliki visi yang jelas dalam pembelajaran dan mampu menjalin ikatan batindengan melakukan perannya sebagai motivator, fasilitator, mediator, dan komunikator. Motivasi sangat diperlukan seperti saat ini masyarakat sedang diuji secara fisik dan mental akibat penyebaran COVID-19 sehingga peserta didik harus mampu beradaptai dengan hal-hal baru di tengah keterbatasan dalam komunikasi, berinteraksi, dan berkreasi.

\section{Kesimpulan}

Pendidikan merupakan faktor pembentuk pribadi individu. Disisi lain, proses perkembangan dan pendidikan manusia tidak hanya terjadi dan dipengaruhi oleh system pendidikan saja. Terdapat tiga lingkungan pendidikan yang ikut serta menjadi perndukung proses pendidikan, yaitu keluarga, sekolah, dan msyarakat. Ketiga lingkungan ini dikenal dengan sebutan tripusat pendidikan. Lingkungan tersebut tidak dapat berdiri sendiri, namun saling mempengaruhi dan saling mendukung antar lingkungan pendidikan.

Keluarga sebagai lingkungan pertama anak menerima pendidikan diingatkan kembali akan peran pentingnya melalui pandemi COVID-19. Keluarga dituntuk dapat mendampingi kegiatan pendidikan anaknya yang semula dilaksanakan di sekolah menjadi belajar dari rumah. Membantu guru dalam mencapai target belajar menjadi tugas keluarga. Saat mendampingi belajar anak, orang tua mampu mengamati karakter yang muncul saat anak menghadapi pembelajaran daring. Kemauan untuk belajar teknologi yang digunakan dalam pembelajaran daring bisa menjadi pengalaman baru bagi orang tua

Sekolah juga memiliki tantangannya sendiri, aturan perubahan pembelajaran langsung menjadi daring menjadikan guru harus mampu merencanakan, melaksanakan dan melakukan evaluasi yang maksimal dengan keterbatasan tatap muka, pemahaman orang tua peserta didik terhadap pembelajaran daring, dan keluhan-keluhan yang muncul saat pembelajaran daring berlangsung. Masyarakat juga diminta segera beradaptasi dengan aturan pembatasan jarak dan perilaku social lainnya. Membiasakan lebih intens menjaga kesehatan dengan protocol-protokol yang telah ditetapkan agar tetap terjaga keselamatan individu yang menjadi anggota dari masyarakat bukan hal yang mudah, tetapi perlu kegigihan. Dengan kerelaan baik dari keluarga, sekolah, dan 
masyarakat memaksimalkan perannya untuk tetap waspada akan dampak buruk pandemic COVID-19 tanpa mengesampingkan kualitas pendidikan, tripusat pendidikan menjadi kesatuan yang kokoh dalam membentu pribadi yang mulia bagi seorang anak.

\section{Daftar Referensi}

Azzet, Akhmad Muhaimin. 2009. Urgensi Pendidikan Karakter di Indonesia. Yogjakarta: Arruz Media.

Daradjat, Zakiah. 1991. Ilmu Pendidikan Islam. Jakarta: Bumi Aksara.

Hatta, Raden Trimutia. 2020. Alasan WHO Tetapkan Virus Corona COVID-19 sebagai Pandemi. https://www.liputan6.com/global/read/4200134/alasan-who-tetapkan-viruscorona-covid-19-sebagai-pandemi (diakses 12 Maret 2020)

Maunah, Binti. 2010. Ilmu Pendidikan. Yogyakarta: Teras.

Pidarta, Made. Landasan Kependidikan Stimulus Ilmu Pendidikan Bercorak Indonesia. Jakarta: Rinekacipta.

Purnamasari, Deti Mega. 2020. Jokowi: Saatnya Kerja dari rumah, Belajar dari Rumah, Ibadah di Rumah. https://nasional.kompas.com/read/2020/03/15/14232961/jokowi-saatnya-kerjadari-rumah-belajar-dari-rumah-ibadah-di-rumah (diakses 15 MAret 2020)

Rahman, Arif. 2011. Memahami Pendidikan dan Ilmu Pendidikan. Yogjakarta: Aswaja Pressindo.

S, Tatang. 2012. Ilmu Pendidikan. Jakarta: Pustaka Setia.

Sa'ud, Undin Syaefudin. 2018. Inovasi Pendidikan. Bandung: Alfabeta.

Sunandar, Asep. 2018. Penjaminan Mutu Pendidikan Proses Pengukuran dan Pengembangan Mutu Pendidikan dengan Teknik FMEA. Malang: Penerbit dan Percetakan Universitas Negeri Malang.

Syaibani, Omar Muhammad al Toumy. 1979. Falsafah Pendidikan Islam. Terjemahan Hasan Langgulung dan Broto. Jakarta: Bulan Bintang.

Tafsir, Ahmad. 2014. Ilmu pendidikan dalam perspekif Islam. Bandung: Remaja Rosdakarya.

Tim Pengembang Ilmu Pendidikan. Ilmu dan Aplikasi Pendididkan Bagian IV. Yogjakarta: PT. Imperial Bhakti Utama.

Van, Doremalen N, dkk. 2020. Aerosol and Surface Stability of SARS-CoV-2 as Compared with SARS-CoV-1. The New England Journal of Medicine. Massachusetts Medical Society. doi:10.1056/nejmc2004973. PMID 32182409 